Publisher homepage: www.universepg.com, ISSN: 2663-7804 (Online) \& 2663-7790 (Print) https://doi.org/10.34104/ajeit.020.031041

Australian Journal of Engineering and Innovative Technology

Journal homepage: www.universepg.com/journal/ajeit

\title{
Effectiveness of Manual Bar Screen in Separating Solid Waste from Municipal Sewers of Khulna City
}

\author{
Jobaer Ahmed Saju ${ }^{1}$, Shah Nawaj Rahman Rubel², Md. Masudur Rahman², Subinoy Biswas Nayan', \\ and Ripon Bagchi ${ }^{3}$
}

${ }^{1}$ Lecturer, Dept. of Civil Engineering, European University of Bangladesh, Dhaka, Bangladesh; ${ }^{2}$ Postgraduate Student, Dept. of Civil Engineering, Khulna University of Engineering and Technology, Khulna, Bangladesh; and ${ }^{3} \mathrm{PhD}$ Fellow, Institute of Disaster Management, Khulna University of Engineering and Technology, Khulna, Bangladesh.

*Correspondence: saju1801504@stud.kuet.ac.bd

\begin{abstract}
In Bangladesh, disposal of raw sewage directly into the streams is common culture. Installing complete wastewater treatment plant everywhere is not possible for developing or least developed countries. Bar screen can be advantageous in separating solid waste from the raw sewage. Solid waste separation from municipal sewage can play an important role in improving the environmental condition. Objective of this study was to observe the effect of bar screen in raw sewage pretreatment. This study was carried out in Khulna city area to investigate the condition of forty-seven outfalls through which the raw sewage is being disposed to the streams. As part of the study, a bar screen was temporarily installed on a drain inside Khulna University of Engineering \& Technology campus. Capability and effect of the temporarily installed bar screen were observed and studied over a period of time. From twelve hours observation of installed bar screen, around 20\% removal found for BOD and COD. Reduction of electrical conductivity (EC) and total dissolved solids (TDS) found near 20\% also. Removal percentage of BOD, COD, EC and TDS obtained higher after one hour of installing the bar screen while 24 hours observation exhibited comparatively lower rate of removal. Optimum condition of bar screen notified at 12 hours which indicated the incorporation of cleaning procedure after every twelve hours to sustain the performance. Furthermore, the differences between raw sewage and bar screen treated sewage were studied; and the possibility of using bar screens on every outfall of Khulna city area was discussed in this study.
\end{abstract}

Keywords: Bar screen, Sewage, Solid waste, Municipal sewers, Khulna city, and Sewage pretreatment.

\section{INTRODUCTION}

Each and every element of raw sewage does carry disadvantages related to the environment. Municipal raw sewage contains certain amount of solid waste which can cause of deterioration of the environmental body. In the purpose of saving nearest municipal streams from the effect raw sewage disposal directly or indirectly, pretreatment of sewage can be beneficial. This study carries the importance of removing solid waste from municipal sewage before disposing it to the streams by implementing raw sewage pretreatment system. The sewers of Khulna City were taken into consideration for this study to investigate the effectiveness of manual bar screen which leads the separation of solid waste from raw sewage.

Khulna is the third largest city of Bangladesh after Dhaka and Chittagong. Khulna is located in southwestern Bangladesh at $22^{\circ} 49^{\prime} 0^{\prime \prime} \mathrm{N} 89^{\circ} 33^{\prime} 0^{\prime \prime} \mathrm{E}$. The city is bounded by Rupsha River on east and south side, Mayur River on west and by Bhairab River by north side. It is the capital of Khulna Division and a major industrial and commercial center. Khulna City Corporation (KCC) covers a total area of 64.78 square kilometers (Bangladesh Bureau of Statistics, 2011). The population of the KCC area is about 0.75 
million as of 2011 and the growth rate is 5\% which is mainly due to rural-urban migration. The city is beset with a number of environmental problems. Water logging, solid waste disposal, black smoke from vehicular and industrial emissions, air and noise pollution, pollution of water bodies by industrial discharge (Rahman et al., 2009; Mehedi, 2017). Drainage and waste disposal facilities of Khulna City discharge a high amount of wastewater, domestic sewage, and solid waste every day. Among all sorts of activities that can pollute a natural water sources, dumping of wastewater and solid waste stands first on the list (Zheng et al., 2010). The magnitude of the dumping is not just alarming but is almost lethal to the native aquatic life. So much so, that the entire aquatic ecosystem of Khulna can be destroyed with this intensity of careless dumping. Future projections indicate that it can be further affected by salinity intrusion and sea level rise due to climate change (ADB, 2010).

About 11.75 million liters/day effluent is discharged through 47 canals and sewers from Khulna City area to the nearby streams (Mridha, 2011). The location of the outlets is shown in Fig 1 below. By visiting a few outlets, it can be stated that the condition of these sewer systems is very substandard, and treatment system is nowhere to be found. At this point, any inexpensive preliminary treatment system can be of great help for the Khulna city.

The purpose of preliminary treatment is to protect the streams from direct disposal of solid waste. Preliminary treatment devices are, therefore, designed to remove or to reduce in size the large, entrained, suspended or floating solids. These solids consist of pieces of wood, cloth, paper, plastics, garbage, etc. together with some fecal matter. Preliminary treatment can remove heavy inorganic solids such as sand and gravel as well as metal or glass. These objects are called grit. It can also help in removing excessive amounts of oils or greases. A number of devices or types of equipment are used to obtain these objectives.

The first step in wastewater treatment is the removal or reduction of coarse solids. The usual procedure is to pass the untreated wastewater through bar racks or screens. Bar screens are normally installed as the first line of defense to remove large objects primarily, rags, woods and rocks that manage to escape and find their way through the sewer systems.

Theoretically around 60 to 70 percent of solid waste from municipal wastewater could be contained by using bar racks (Metcalf and Eddy, 2003). In this case, where we are considering direct disposal of sewage water, bar screen treated wastewater should be marginally better as it contains better amount of Dissolved Oxygen (DO), reduced total dissolved solid (TDS), COD and BOD level if we compare it with untreated water. As the major part of solid waste can be deducted by using bar screens so it would certainly make a difference to the quality of river water where direct disposal of raw sewage happens on a regular basis (Hamid et al., 2013). An understanding of the nature of wastewater is essential in the design and operation of treatment, and disposal facilities; in the engineering management of environmental quality.

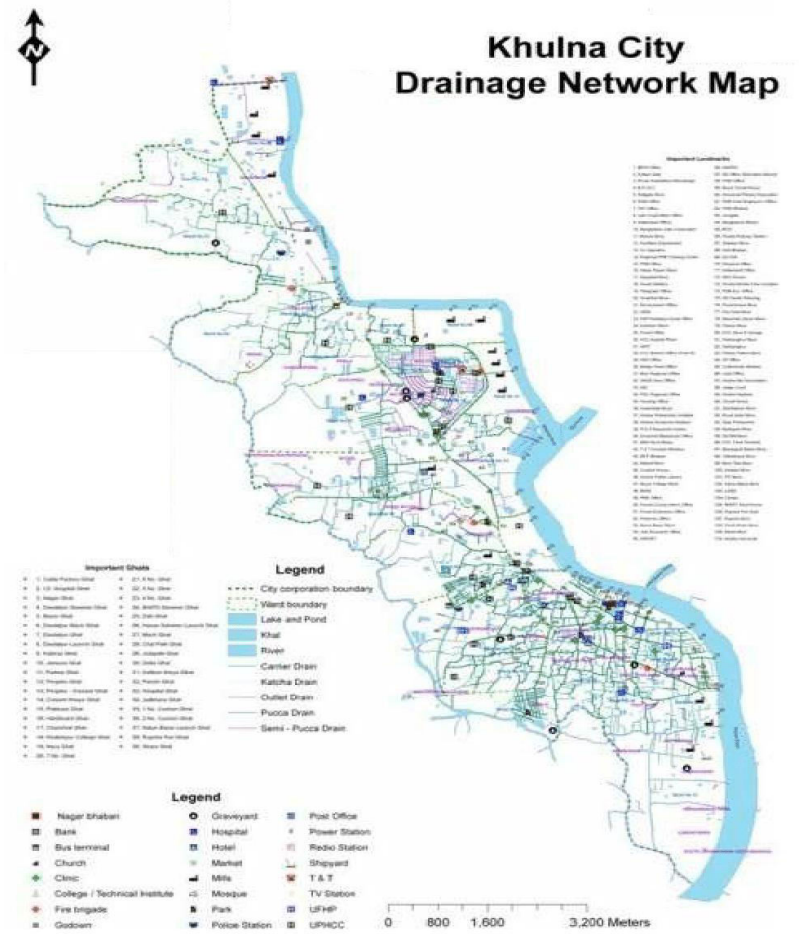

Fig 1: Location of the drainage outlets of Khulna City.

Though, a number of studies have investigated the characteristics of wastewater in Khulna city, no study was conducted to identify the impact of inexpensive pretreatment system such as bar screen. The specific objectives of the study are: (i) to identify the existing drainage condition and management system of wastewater in Khulna City; (ii) to understand how poor solid waste management affects drainage system as well as public health in 
the area and propose how bar screen system can be a great alternative to prevent buildup; (iii) to evaluate the suitability of bar screen for the preliminary treatment of wastewater in Khulna City; (iv) to evaluate the difference in characteristics of untreated and bar screen treated wastewater; and (v) to check the feasibility of installing bar screen on every outfall of Khulna municipal area.

\section{MATERIALS AND METHODS}

Before going to a final study, a procedural setup has to be fixed to undertake the possible all work to fulfill the objectives. Criteria fixation, types of data collection, time duration, quantity of data etc. are some major tasks have to be done. This organizational setup and working procedure are called as methodology as our concern. The methodological analysis has some certain section in this project concerned.

\section{Selection of the Study Area}

The scoping study relied on both primary and secondary information. A field survey within Khulna municipal area was conducted to get the primary data during February 2018 to May 2018. Map of existing drainage system and outfalls were collected from Khulna City Corporation (KCC) and Khulna Development Authority (KDA). Other maps were collected from word book for Khulna city. Other data was collected through reconnaissance survey, direct observation, and community consultations. Secondary data was collected from different sources including published and unpublished literature, different databases, newspapers and the World Wide Web.

Among the observed 47 outfalls, the one near Khulna University of Engineering and Technology found to be one of the easiest to access for the team. That's why the KUET campus sewer directly connected to the outfall was considered for the study. Location of the study area in context of Bangladesh and Khulna district is shown in Fig 2. The observed drainage system was found out to be both directly and indirectly linked with the water bodies of Khulna city. The study site was visited to understand and identify the major problems and issues related to solid waste dumping and benefit of solid waste removal using bar screen.

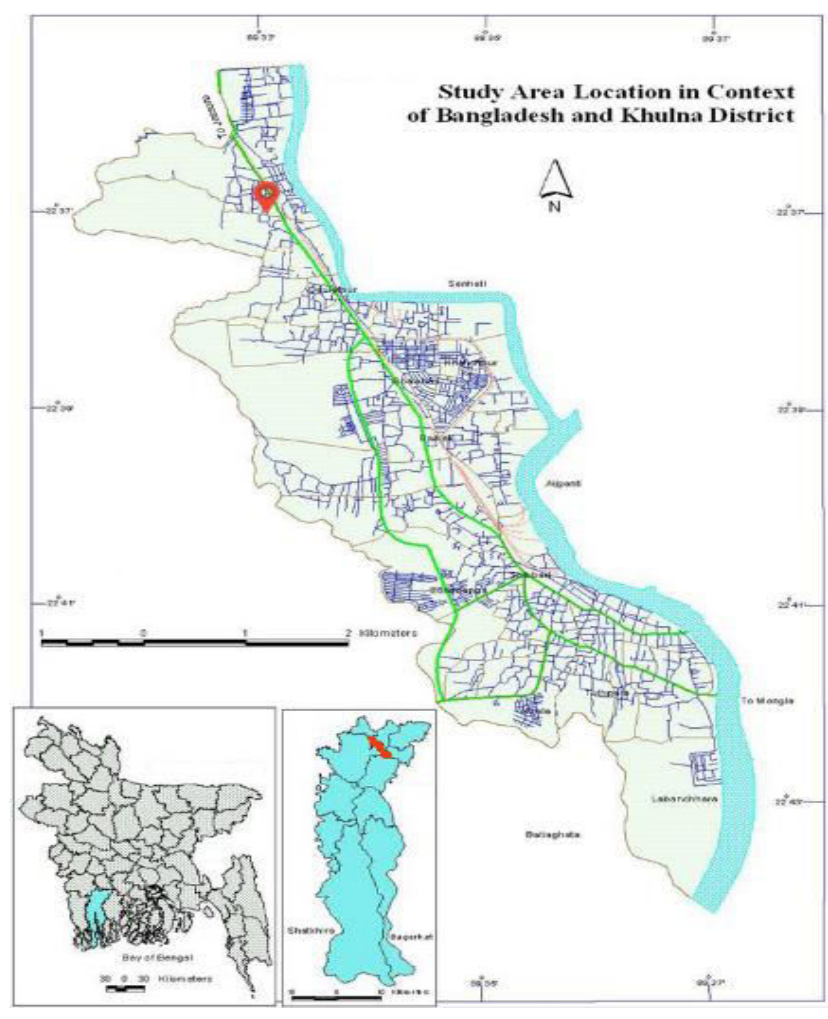

Fig 2: Location of the study area.

\section{Wastewater Characteristics}

Municipalities are faced with the problem of disposing of wastes. This includes all solid waste products which are composed wholly or partly of such materials as garbage, sweepings, cleanings, trash, rubbish, litter, industrial solid wastes or domestic solid wastes including organic wastes or residues of animals, meat, fruit, vegetables, grains or fish; animal excreta or carcasses of animals; rubbish including wood, leaves, vegetation, tree trimmings, dead trees and shrubs, branches, sawdust, shavings, grass, paper products, straw, rags, clothing.

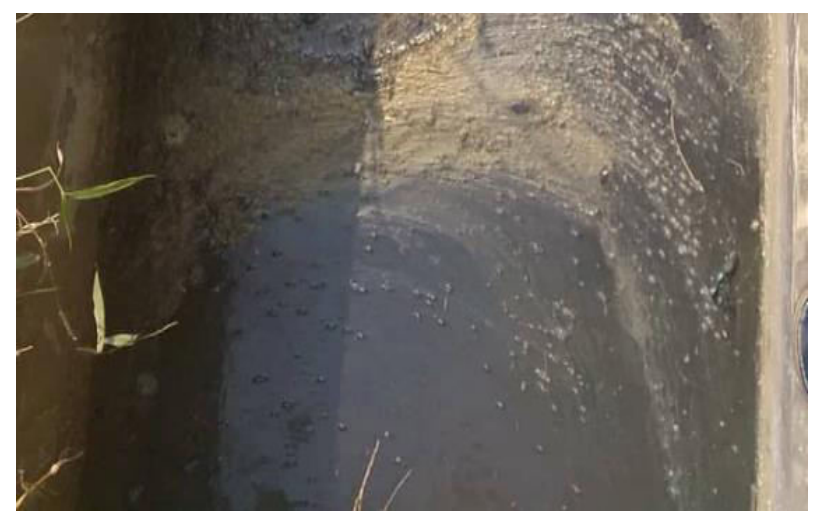

Fig 3: Condition of the observed drain.

All other combustibles; waste matter composed of soil, clay, sand, earth, gravel, fill, stones, bricks, plaster, glass, glassware, crockery, ashes, cinders, 
shells, metal and other non-combustibles; waste debris resulting from the construction, demolition, repair, or alteration of structures or buildings; accumulated waste materials composed of cans, containers, tires, junk, vehicle parts or other substances which may become a nuisance. Condition of the selected drain can be seen in Fig 3 .

\section{Selection of Parameters for Wastewater}

Each sample of the collected wastewater was tested for various Physio-Chemical parameters. $\mathrm{pH}, \mathrm{EC}$, TDS, BOD, COD, and DO were analyzed to test the water quality of selected drain to understand the effectiveness of solid waste removal using bar screen (Rubel et al., 2019). The results were compared with Department of Environment (DoE, 1997) and World Health Organization (WHO) standards. The characteristics of wastewater and standards are showed in Table 1. From the observation, it can be said that the TDS, EC, COD and BOD of the wastewater is quite high, $\mathrm{pH}$ level is acidic and dissolved oxygen is substandard.

\section{Design Parameters of Bar Screen}

Bar screens may be hand cleaned or mechanically cleaned. Hand cleaned bar screens are frequently used in small sewer system. That's why a manual bar screen was considered our study. It should be noted that manual bar screen must not exceed the distance that can be conveniently raked by hand (approximately $10 \mathrm{ft}$ ). The rack bars should not be less than 3/8-inch-thick by 2 inch deep. They should be welded to spacing bars located at the rear face, out of the way of the tines of the rake (Metcalf and Eddy, 2003). For this study, considering every factor, a $3.3 \mathrm{ft}$ long bar screen made of 0.2-inchthick and 1-inch deep flat bar was used. Characteristics of the constructed manual bar screen is shown in Table 1. Schematic diagram and experimental set-up of the bar screen considered for this study are shown in Fig 4.

Table 1: Characteristics of the considered manual bar screen.

\begin{tabular}{|l|c|c|}
\hline \multicolumn{1}{|c|}{ Items } & Standard for Manual Bar Screen & Considered Measurement \\
\hline Bar size: & & 0.2 \\
\hline Width, in & $0.2-0.6$ & 1.0 \\
\hline Depth, in & $1.0-1.5$ & 1.0 \\
\hline Clear spacing between bars, in & $1.0-2.0$ & 45 \\
\hline Slope from vertical, degree & $30-45$ & 1.5 \\
\hline Approach velocity, ft/s & $1.0-2.0$ & \\
\hline
\end{tabular}
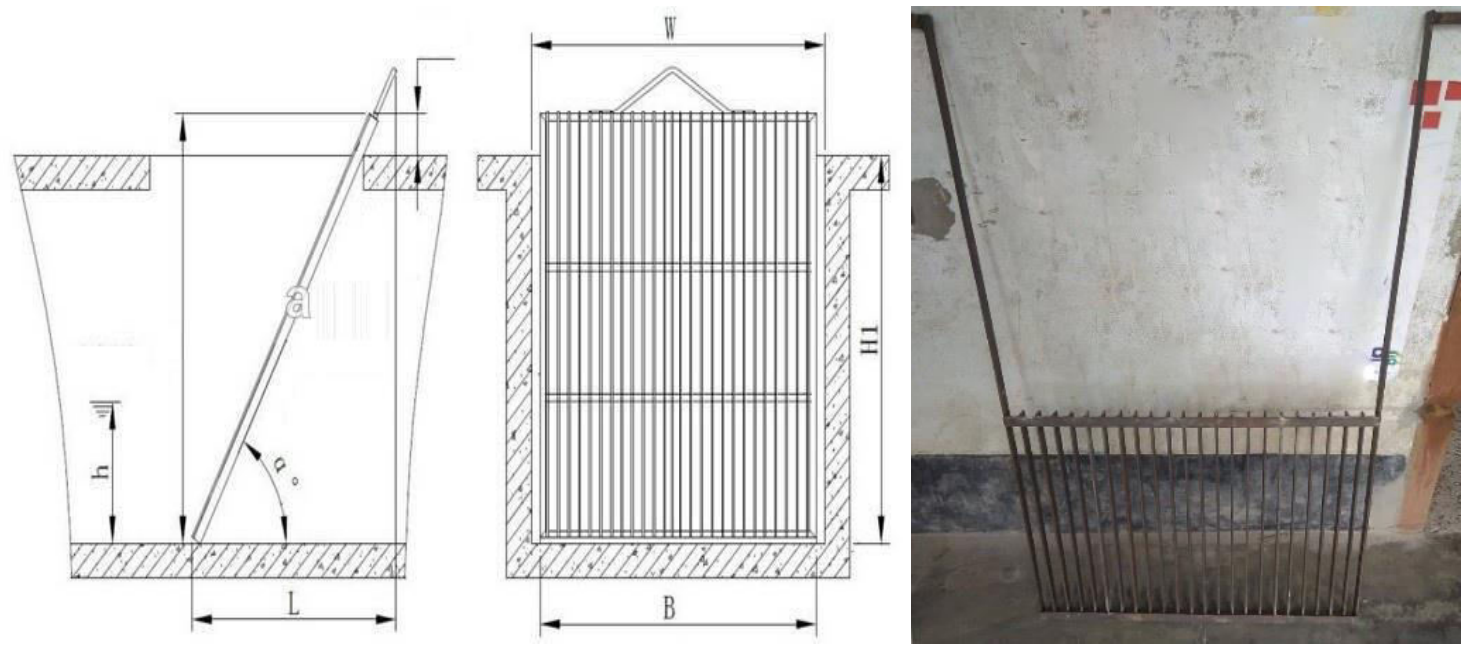

Fig 4: Schematic diagram and experimental set-up of the bar screen.

\section{Wastewater Sample Analysis}

Samples were collected before installing the bar screen, 1 hour after installation of bar screen and then 4 more times with 6 hours interval. Fig 5 shows the condition of the drain at different times when samples were collected. Collected samples were transported to the environmental engineering lab of 
Khulna University of Engineering \& Technology, where the characteristics of the wastewater were observed. Dissolved oxygen (DO), Electrical Conductivity (EC), and $\mathrm{pH}$ were monitored with different electrochemical probes. Chemical Oxygen Demand (COD) was measured by using COD digester and spectrophotometer. The Biochemical Oxygen Demand $\left(\mathrm{BOD}_{5}\right)$ test procedure was conducted based on DO concentration and required an accurate DO determination. Total Dissolved Solids (TDS) was calculated by evaporating the sample wastewater and weighing the solid residue. Sample preparation for chemical oxygen demand, suspended solids and total solids are shown in Fig 6 and 7.
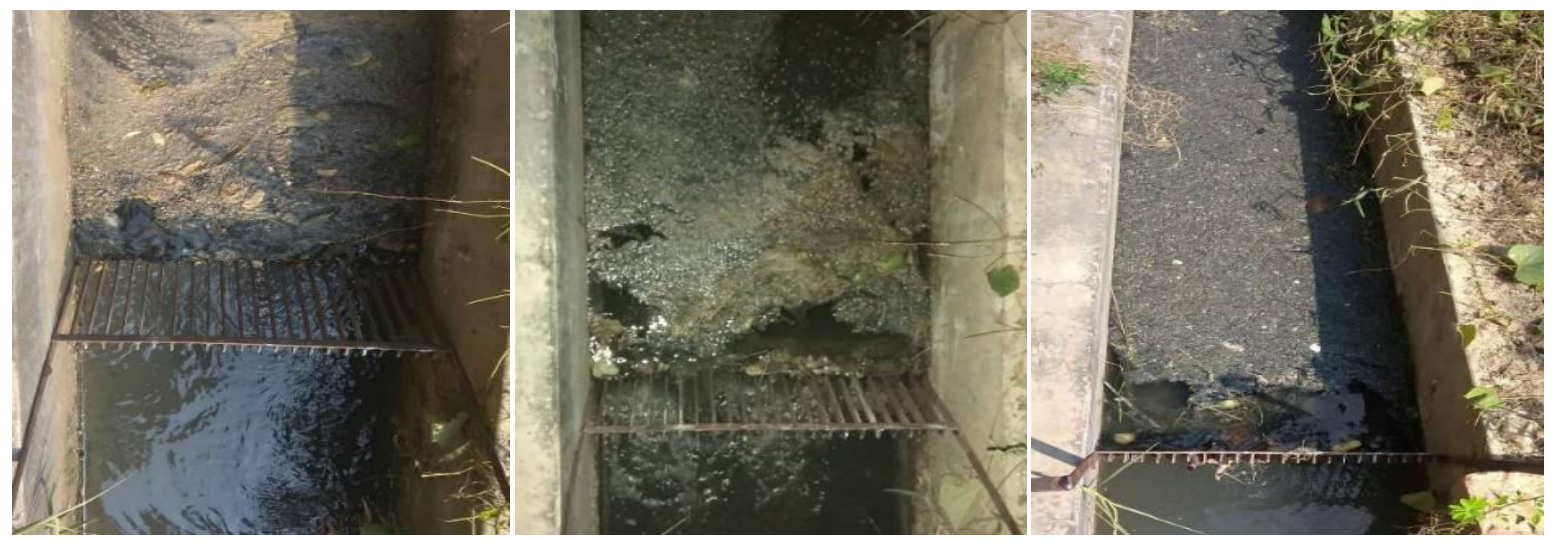

Fig 5: Observation of the drain after 1, 12 and 24 hours of installing the bar screen.
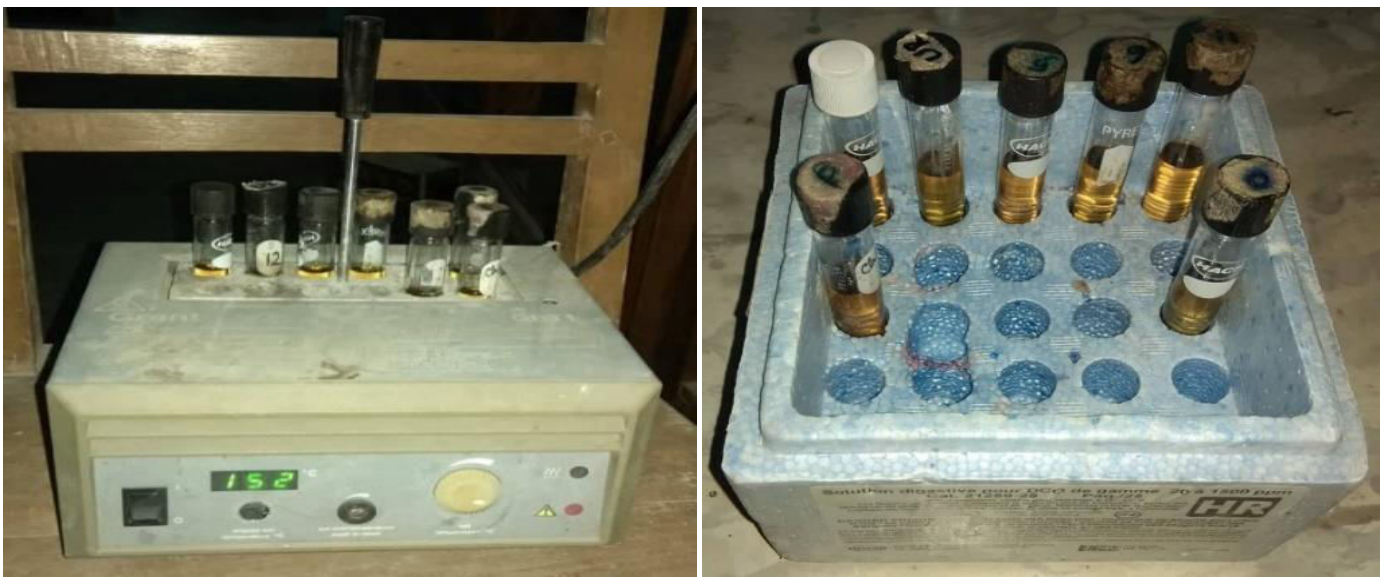

Fig 6: Sample preparation for the calculation of COD.

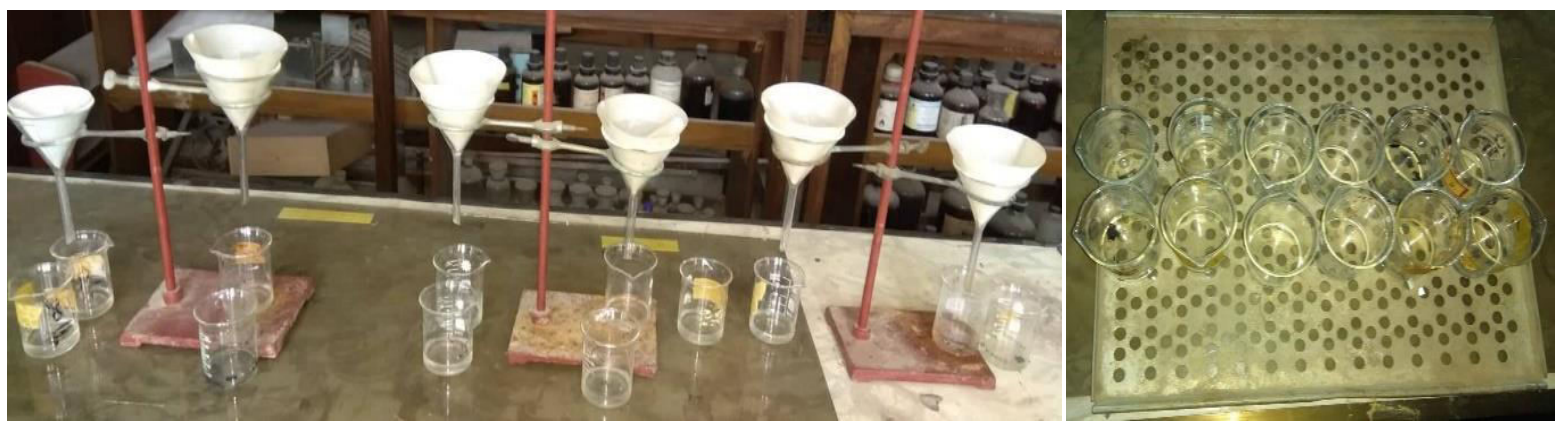

Fig 7: Sample preparation for suspended solids and total dissolved solids.

\section{RESULTS AND DISCUSSION}

The focus of the study was to quantitatively characterize the solid waste load in the major drains of the Khulna city and to assess the suitability of bar screen for solid waste removal. Samples of waste water collected 6 different times within 24 hours from the selected drain and were analyzed for parameters including $\mathrm{pH}, \mathrm{EC}, \mathrm{TDS}, \mathrm{BOD}, \mathrm{COD}$, and DO. The results of the analysis of these physical and chemical parameters are shown in Table 2 to Table 6. 
Table 2: Results of Physio-chemical parameters of wastewater of the drain after 1 hour of installing the bar screen and its comparison with DoE standard.

\begin{tabular}{|l|l|c|c|c|c|}
\hline Parameter & Unit & DoE Standard & $\begin{array}{c}\text { Sewage } \\
\text { Without bar screen }\end{array}$ & $\begin{array}{c}\text { Bar screen } \\
\text { treated sewage }\end{array}$ & $\begin{array}{c}\text { Sewage at bar screen } \\
\text { where waste retained }\end{array}$ \\
\hline $\mathrm{pH}$ & - & $6-9$ & 5.95 & 6.22 & 6.08 \\
\hline $\mathrm{DO}$ & $\mathrm{mg} / \mathrm{L}$ & $4.5-8$ & 4.9 & 5.2 & 4.7 \\
\hline $\mathrm{BOD}_{5}$ & $\mathrm{mg} / \mathrm{L}$ & 250 & 170.19 & 112.78 & 181.70 \\
\hline $\mathrm{COD}$ & $\mathrm{mg} / \mathrm{L}$ & 400 & 395.16 & 235.56 & 403.39 \\
\hline $\mathrm{EC}$ & $\mu \mathrm{S} / \mathrm{cm}$ & 1200 & 795 & 685 & 835 \\
\hline $\mathrm{TDS}$ & $\mathrm{mg} / \mathrm{L}$ & 2100 & 1100 & 800 & 1190 \\
\hline
\end{tabular}

Table 3: Results of Physio-chemical parameters of wastewater of the drain after 6 hours of installing the bar screen and its comparison with DoE standard.

\begin{tabular}{|l|l|c|c|c|c|}
\hline Parameter & Unit & DoE Standard & $\begin{array}{c}\text { Sewage } \\
\text { Without bar screen }\end{array}$ & $\begin{array}{c}\text { Bar screen } \\
\text { treated sewage }\end{array}$ & $\begin{array}{c}\text { Sewage at bar screen } \\
\text { where waste retained }\end{array}$ \\
\hline $\mathrm{pH}$ & - & $6-9$ & 5.95 & 6.20 & 5.9 \\
\hline $\mathrm{DO}$ & $\mathrm{mg} / \mathrm{L}$ & $4.5-8$ & 4.9 & 5.1 & 4.5 \\
\hline $\mathrm{BOD}_{5}$ & $\mathrm{mg} / \mathrm{L}$ & 250 & 170.19 & 133.15 & 219.04 \\
\hline $\mathrm{COD}$ & $\mathrm{mg} / \mathrm{L}$ & 400 & 395.16 & 316.39 & 478.02 \\
\hline $\mathrm{EC}$ & $\mu \mathrm{S} / \mathrm{cm}$ & 1200 & 795 & 639 & 878 \\
\hline $\mathrm{TDS}$ & $\mathrm{mg} / \mathrm{L}$ & 2100 & 1100 & 820 & 1380 \\
\hline
\end{tabular}

Table 4: Results of Physio-chemical parameters of wastewater of the drain after 12hours of installing the bar screen and its comparison with DoE standard.

\begin{tabular}{|l|l|c|c|c|c|}
\hline Parameter & Unit & $\begin{array}{c}\text { DoE } \\
\text { Standard }\end{array}$ & $\begin{array}{c}\text { Sewage } \\
\text { Without bar screen }\end{array}$ & $\begin{array}{c}\text { Bar screen } \\
\text { treated sewage }\end{array}$ & $\begin{array}{c}\text { Sewage at bar screen where } \\
\text { waste retained }\end{array}$ \\
\hline $\mathrm{pH}$ & - & $6-9$ & 5.95 & 6.21 & 5.9 \\
\hline $\mathrm{DO}$ & $\mathrm{mg} / \mathrm{L}$ & $4.5-8$ & 4.9 & 5 & 4.4 \\
\hline $\mathrm{BOD}_{5}$ & $\mathrm{mg} / \mathrm{L}$ & 250 & 170.19 & 135.20 & 230.38 \\
\hline $\mathrm{COD}$ & $\mathrm{mg} / \mathrm{L}$ & 400 & 395.16 & 326.56 & 571.95 \\
\hline $\mathrm{EC}$ & $\begin{array}{l}\mu \mathrm{S} / \mathrm{c} \\
\mathrm{m}\end{array}$ & 1200 & 795 & 647 & 953 \\
\hline $\mathrm{TDS}$ & $\mathrm{mg} / \mathrm{L}$ & 2100 & 1100 & 830 & 1450 \\
\hline
\end{tabular}

Table 5: Results of Physio-chemical parameters of wastewater of the drain after 18 hours of installing the bar screen and its comparison with DoE standard.

\begin{tabular}{|l|l|c|c|c|c|}
\hline Parameter & Unit & DoE Standard & $\begin{array}{c}\text { Sewage Without } \\
\text { bar screen }\end{array}$ & $\begin{array}{c}\text { Bar screen } \\
\text { treated sewage }\end{array}$ & $\begin{array}{c}\text { Sewage at bar screen } \\
\text { where waste retained }\end{array}$ \\
\hline $\mathrm{pH}$ & - & $6-9$ & 5.95 & 6.07 & 5.4 \\
\hline $\mathrm{DO}$ & $\mathrm{mg} / \mathrm{L}$ & $4.5-8$ & 4.9 & 4.7 & 4.4 \\
\hline $\mathrm{BOD}_{5}$ & $\mathrm{mg} / \mathrm{L}$ & 250 & 170.19 & 140.78 & 245.39 \\
\hline $\mathrm{COD}$ & $\mathrm{mg} / \mathrm{L}$ & 400 & 395.16 & 341.20 & 611.48 \\
\hline $\mathrm{EC}$ & $\mu \mathrm{S} / \mathrm{cm}$ & 1200 & 795 & 701 & 1037 \\
\hline $\mathrm{TDS}$ & $\mathrm{mg} / \mathrm{L}$ & 2100 & 1100 & 890 & 1500 \\
\hline
\end{tabular}


Table 6: Results of Physio-chemical parameters of wastewater of the drain after 24 hours of installing the bar screen and its comparison with DoE standard.

\begin{tabular}{|l|l|c|c|c|c|}
\hline Parameter & Unit & $\begin{array}{c}\text { DoE } \\
\text { Standard }\end{array}$ & $\begin{array}{c}\text { Sewage } \\
\text { Without bar screen }\end{array}$ & $\begin{array}{c}\text { Bar screen } \\
\text { treated sewage }\end{array}$ & $\begin{array}{c}\text { Sewage at bar screen } \\
\text { where waste retained }\end{array}$ \\
\hline $\mathrm{pH}$ & - & $6-9$ & 5.95 & 6.10 & 5.35 \\
\hline $\mathrm{DO}$ & $\mathrm{mg} / \mathrm{L}$ & $4.5-8$ & 4.9 & 4.8 & 4.2 \\
\hline $\mathrm{BOD}_{5}$ & $\mathrm{mg} / \mathrm{L}$ & 250 & 170.19 & 154.86 & 298.27 \\
\hline $\mathrm{COD}$ & $\mathrm{mg} / \mathrm{L}$ & 400 & 395.16 & 349.71 & 642.53 \\
\hline $\mathrm{EC}$ & $\mu \mathrm{S} / \mathrm{cm}$ & 1200 & 795 & 756 & 1280 \\
\hline $\mathrm{TDS}$ & $\mathrm{mg} / \mathrm{L}$ & 2100 & 1100 & 940 & 1670 \\
\hline
\end{tabular}

Table 2 to Table 6 shows that the physio-chemical parameters were substandard without bar screen when comparing with the DoE standard, and bar screen treated sewage showed good improvement. In general, the performance of the test bar screen system is satisfactory with high removal efficiencies for organic matter, suspended solids, BOD and COD with slight $\mathrm{DO}$ and $\mathrm{pH}$ levels improvements.

\section{Performance of Tested Manual Bar Screen}

Fig 8 and 9 represent the variations of $\mathrm{BOD}_{5}$ and COD between the sewage before the installation of bar screen and bar screen treated sewage. Subsequently, Fig $\mathbf{1 0}$ and $\mathbf{1 1}$ represent the variation of EC and TDS between the sewage before the installation of bar screen and bar screen treated sewage.

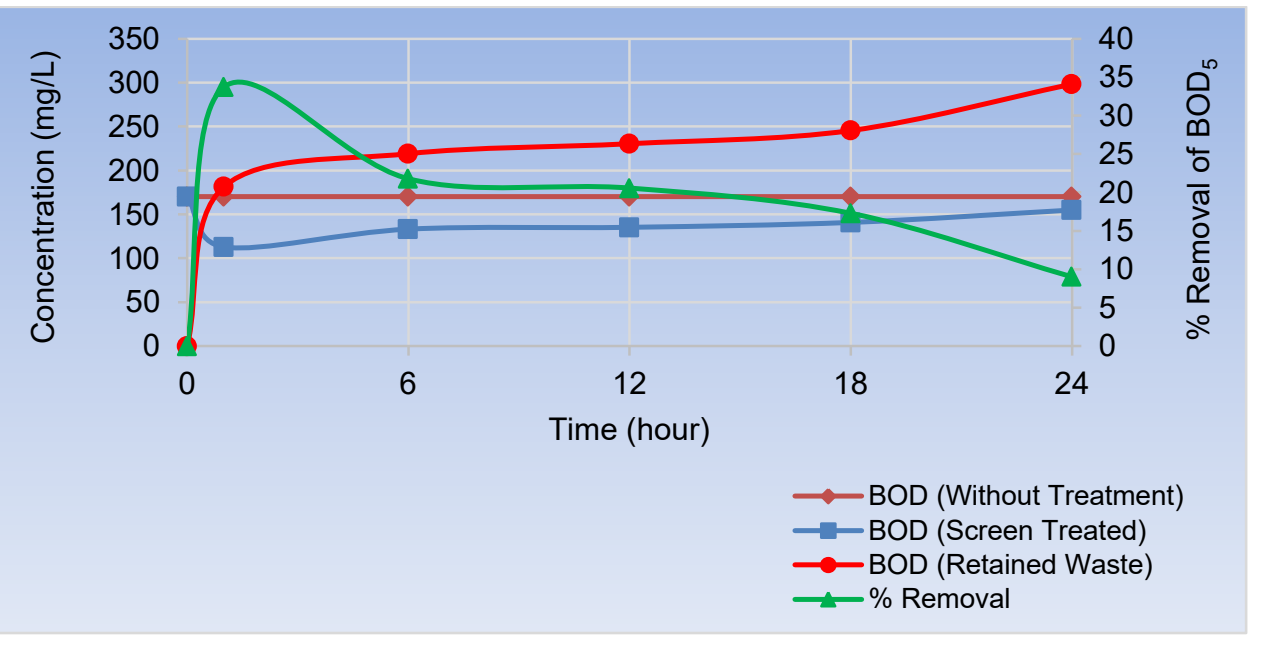

Fig 8: Variations of $\mathrm{BOD}_{5}$ of the drain within 24 hours of installing the bar screen.

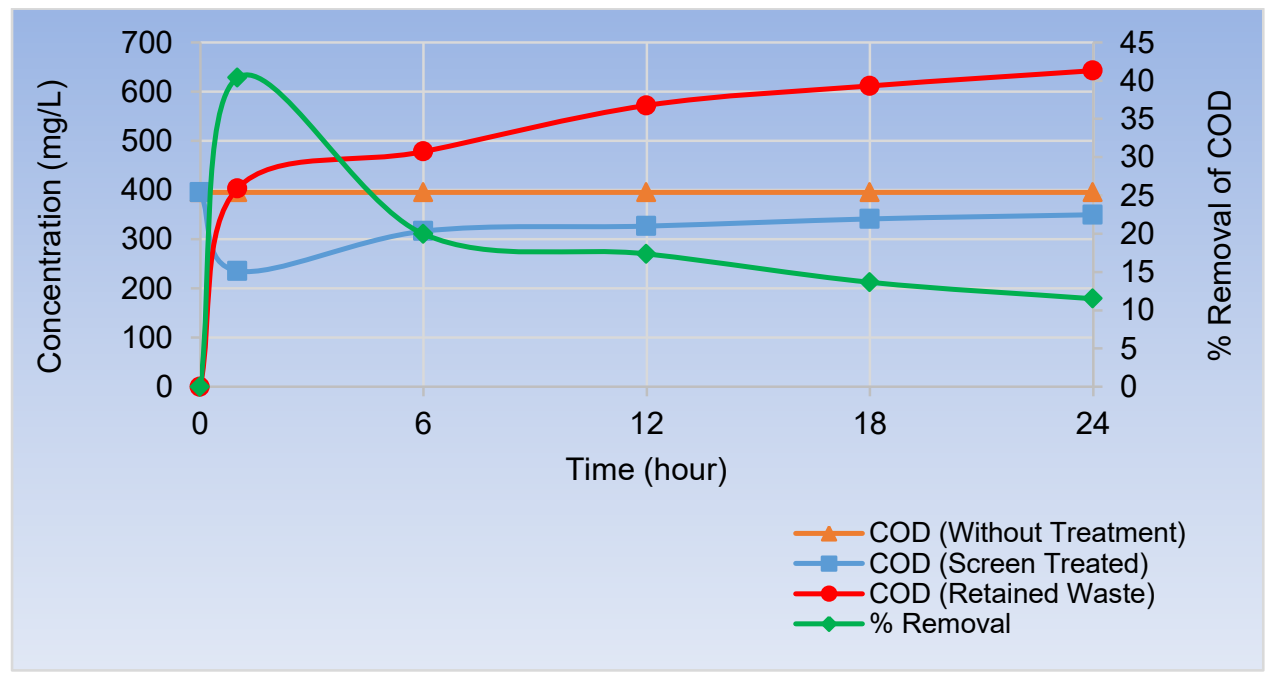

Fig 9: Variations of COD of the drain within 24 hours of installing the bar screen. 
Observation of Fig 8 and 9 shows that, at first hour or just at the time of installing bar screen, the $\mathrm{BOD}_{5}$ was $170.19 \mathrm{mg} / \mathrm{L}$ and COD was about $395.16 \mathrm{mg} / \mathrm{L}$. The $\mathrm{BOD}_{5}$ level of the treated sewage becomes $112.78 \mathrm{mg} / \mathrm{L}$, and the COD level becomes 235.56 $\mathrm{mg} / \mathrm{L}$ after 1 hour, which occurred due to decreased number of solid waste and organic matter in the treated sewage. With the time passes, solid waste and organic matter was continuously retained by the bar screen, hence the $\mathrm{BOD}_{5}$ and COD level of the treated sewage decreases; subsequently $\mathrm{BOD}_{5}$ and COD level of the sewage where the waste was retained at the bar screen increases. The $\mathrm{BOD}_{5}$ level of the treated sewage becomes $133.15 \mathrm{mg} / \mathrm{L}$ after 6 hours, $135.20 \mathrm{mg} / \mathrm{L}$ after 12 hours, $140.78 \mathrm{mg} / \mathrm{L}$ after 18 hours and $154.86 \mathrm{mg} / \mathrm{L}$ after 24 hours. Subsequently the COD level of the treated sewage becomes $316.39 \mathrm{mg} / \mathrm{L}$ after 6 hours, $326.56 \mathrm{mg} / \mathrm{L}$ after 12 hours, $341.20 \mathrm{mg} / \mathrm{L}$ after 18 hours and $349.71 \mathrm{mg} / \mathrm{L}$ after 24 hours. The result shows the gradually increasing level of $\mathrm{BOD}_{5}$ and $\mathrm{COD}$ of the treated sewage especially after 12 hours, which indicates the effectiveness of the bar screen at first 12 hours and the decreasing efficiency of the screen at later hours which occurred due to huge amount of retained solid waste and organic matter at the screen.

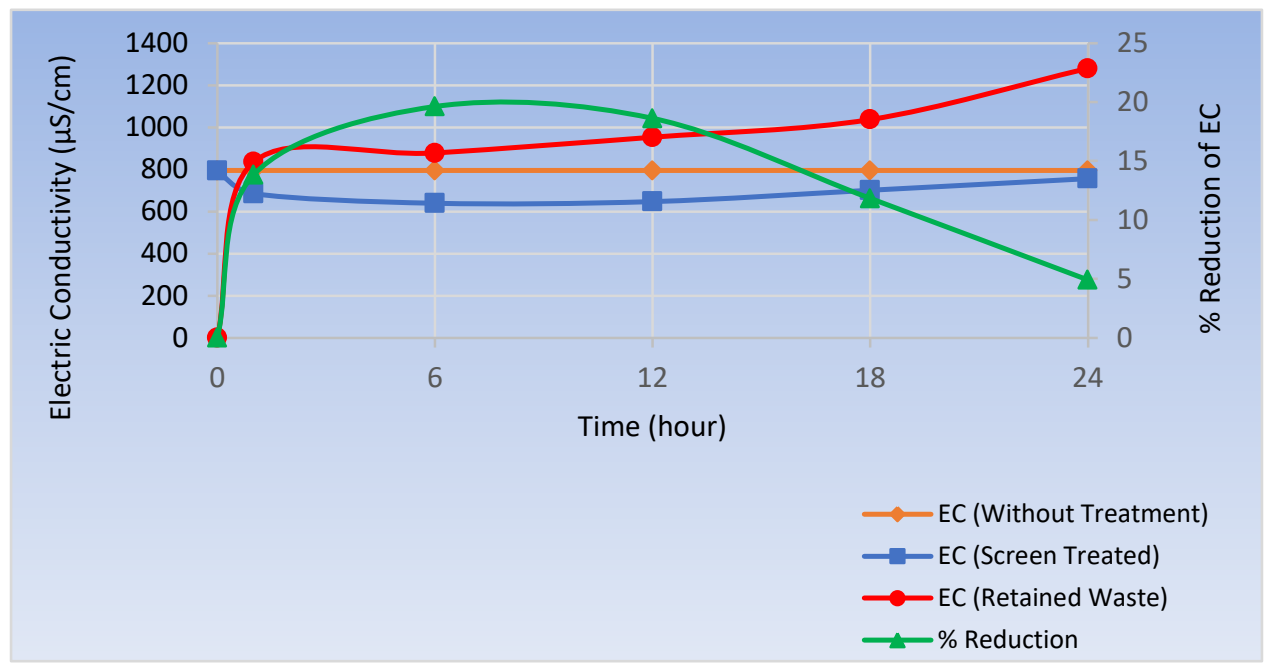

Fig 10: Variations of Electrical Conductivity of the drain within 24 hours of installing the bar screen.

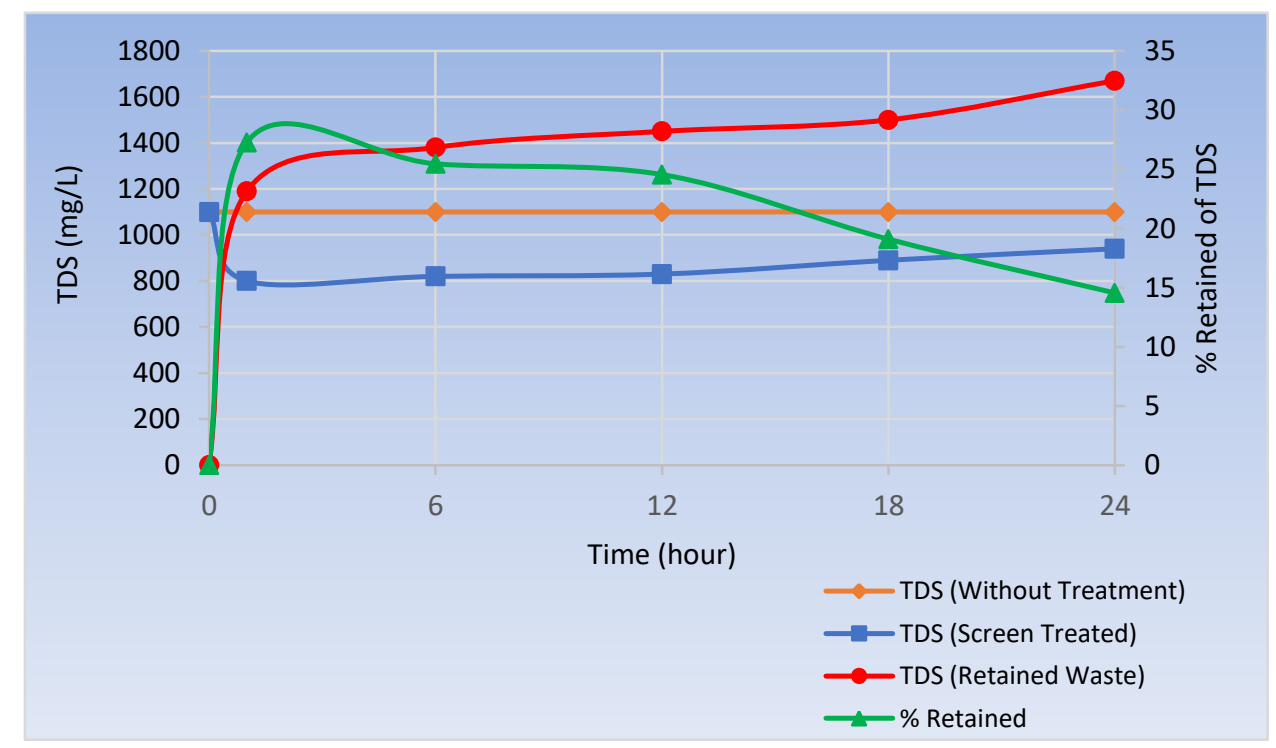

Fig 11: Variations of Total Dissolved Solids of the drain within 24 hours of installing the bar screen.

EC is the capacity of water to conduct current, which is caused by the presence of salts, acids and bases, called electrolytes, capable of producing cations and anions (Goel, 2006). Conductivity is an early indicator of change in a water system. Conductivity and TDS have strong correlation. 
According to Fig 10 and 11, the EC was $795 \mu \mathrm{S} / \mathrm{cm}$ and TDS was about $1100 \mathrm{mg} / \mathrm{L}$ at the beginning. After 1 hour, the EC level of the treated sewage reduced to685 $\mu \mathrm{S} / \mathrm{cm}$, and the TDS level becomes $800 \mathrm{mg} / \mathrm{L}$, which occurred due to decreased number of solid wastes in the treated sewage. As the time passes, solid waste was continuously retained by the bar screen, hence the reduction of EC and TDS level of the treated sewage; subsequently EC and TDS level of the sewage where waste retained at the bar screen increased. The EC level of the treated sewage becomes $639 \mu \mathrm{S} / \mathrm{cm}$ after 6 hours, $647 \mu \mathrm{S} / \mathrm{cm}$ after 12 hours, $701 \mu \mathrm{S} / \mathrm{cm}$ after 18 hours and $756 \mu \mathrm{S} / \mathrm{cm}$ after 24 hours. Subsequently the TDS level of the treated sewage becomes $820 \mathrm{mg} / \mathrm{L}$ after 6 hours, $830 \mathrm{mg} / \mathrm{L}$ after 12 hours, $890 \mathrm{mg} / \mathrm{L}$ after 18 hours and 940 $\mathrm{mg} / \mathrm{L}$ after 24 hours. One of the main sources for TDS of the observed drain is solid waste and that's why their levels were high before the treatment and was highest where the solid waste was retained by the bar screen. The result shows the gradually increasing level of EC and TDS of the treated sewage especially after 12 hours, which indicates the effectiveness of the bar screen at first 12 hours. From the graph, it is observed that the rate of the removal of EC and TDS decrease after 12 hours and the removal rate continued to decrease gradually after that. This indicates the importance of manual cleaning every 12 hours for better result.

\section{Benefits of Using Bar Screen in Every Outfall within the City}

Mayur River receives the most sewage from the urban part of Khulna City. There are about 25 canals and sewer that drain out the effluents from Khulna City Corporation (KCC) area to the Mayur River. The locations of the effluents through sewers are shown in Fig 12. As observed, the drainage facilities of Khulna City discharge a large amount of wastewater by the outlets into the river.

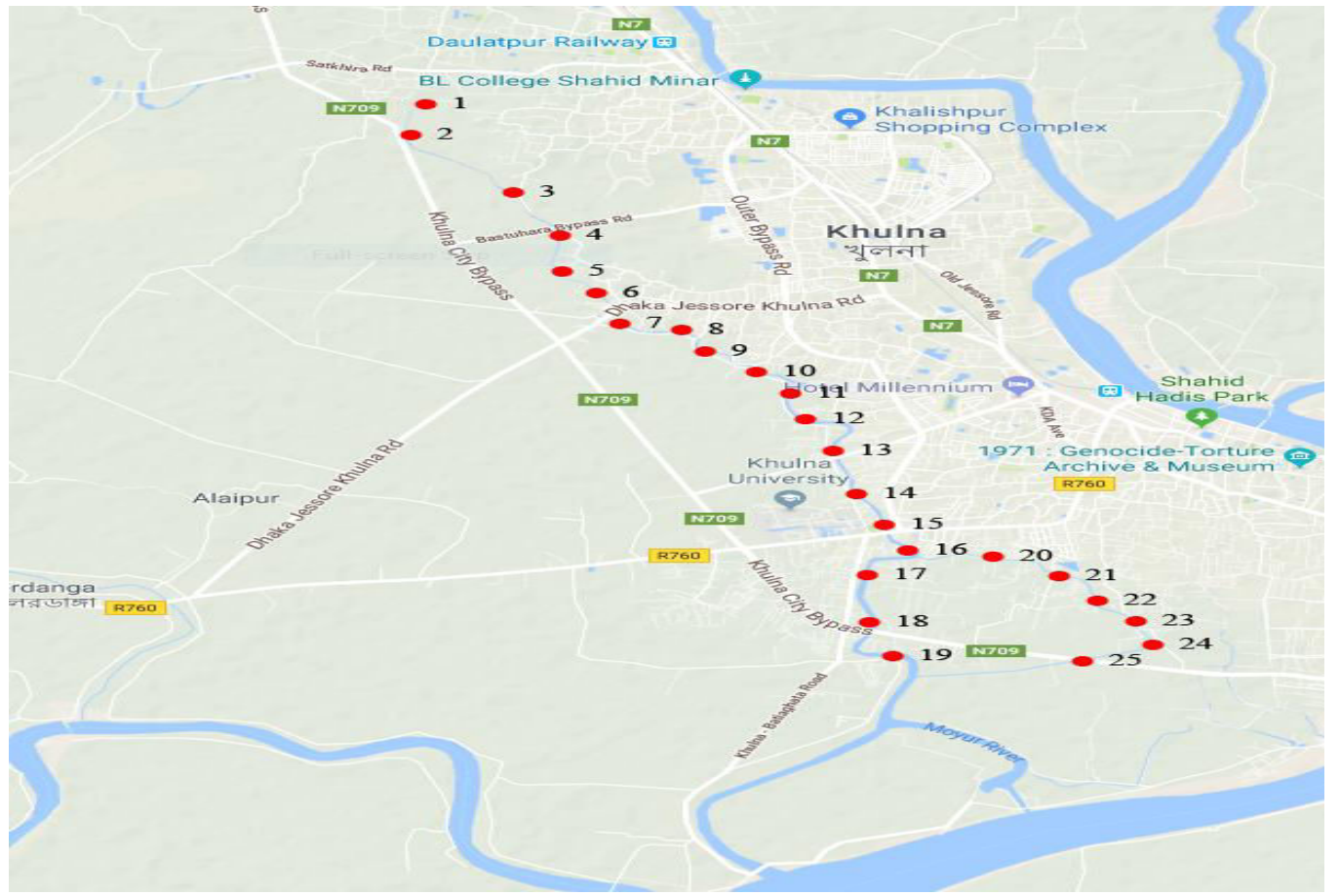

Fig 12: Location of sewers discharging sewage to Mayur River.

Table 7: Water quality of Sewage and Mayur River compared with water quality standards.

\begin{tabular}{|c|c|c|c|c|c|}
\hline \multirow{2}{*}{ Parameters } & \multirow{2}{*}{$\begin{array}{c}\text { Sewage of } \\
\text { Sonadanga Outfall }\end{array}$} & \multicolumn{2}{|c|}{ Mayur River at Gollamari Bridge } & \multicolumn{2}{|c|}{ Standard } \\
\cline { 3 - 6 } & & High Tide & Low Tide & DoE & WHO \\
\hline DO (mg/L) & 0.7 & 2.7 & 2.9 & 5 & - \\
\hline EC (dS/m) & 1.8 & 14.1 & 16.2 & 2.25 & $0-3$ \\
\hline TDS (mg/L) & 1004.1 & 6230.2 & 8005.6 & 1000 & $0-2000$ \\
\hline
\end{tabular}


Outfall near Sonadanga is found to be one of the biggest among the observed 25 in discharging raw sewage to Mayur River. From wastewater and river water quality measurement, Table 7 presents the quality of sewage for Sonadanga outfall and river condition near Gollamari Bridge.

DO was very low near the outfall which regained some oxygen near the bridge, but even that was below doe or who standard. TDS at the outfall was tolerable but results from the observation of this study show that the solid waste eventually dissolves into the river water and make the situation even worse by increasing the TDS and conductivity of the water and which can be easily remedied by installing a bar screen.

Based on the report conducted by Mridha in 2011, about 11.75 million liters/day effluent is discharged through 47 canals and sewers from Khulna City area to the nearby streams. Installing bar screen can improve the BOD and COD level of the sewage by about $20 \%$ and reduce the TDS by about $25 \%$, if the screen is cleaned every 12 hours. If it is possible to install bar screen on all 47 outfalls, quality of 11.75 million liter/day of sewage can be improved in the same way. This can greatly benefit the water quality of the streams of Khulna city.

\section{CONCLUSION}

The main purpose of drains should be collecting municipal effluents. But due to lack of awareness, the drains of Khulna city have been used to collect solid wastes of diverse nature. This can be remedied by screening out the solid wastes from sewage by bar screens. The result of this study shows that detainment of solid wastes by the bar screen exhibited an important potential to reduce COD, $\mathrm{BOD}_{5}, \mathrm{EC}$ and TDS. Thus, it provides strong evidence that the drains of Khulna City area can be greatly benefitted by installing bar screen in every major outfall. Therefore, there is an urgent need to take essential steps to install bar screen and remove solid waste before discharging sewage into the water bodies. So that pollution load can be minimized, natural water bodies can be preserved and the water can be used for beneficial purposes very efficiently. Study on the surface and subsurface runoff and effect of climate change on the drainage system could be helpful for better understanding of the situation. A detailed study can be conducted on implementation of the mechanically cleaned bar screen in the Khulna city as well.

\section{ACKNOWLEDGEMENT}

Thanks to the co-author supported with proper assistance and help for data analysis and writing to conduct successful research.

\section{CONFLICTS OF INTEREST}

The authors declare that they have no potential conflicts with respect to the research work.

\section{REFERENCES}

1. Asian Development Bank, (2010). Bangladesh: Strengthening the Resilience of the Water Sector in Khulna to Climate Change, Technical Assistance Consultant's Report, Final Report prepared by Institute of Water Modeling, Bangladesh, Manila: Asian Development Bank.

2. Bangladesh Bureau of Statistics, (2011). Area, Population and Literacy Rate by Paurashava-2011, Government of Bangladesh.

http://203.112.218.65:8008/WebTestApplica tion/userfiles/Image/District\%20Statistics/D haka.pdf

3. Department of Environment (DoE), (1997). Water Quality Standards for Drinking Water and Irrigation. Dhaka: Ministry of Environment and Forest, Government of Bangladesh.

4. Goel, P. K. (2006). Water pollution: causes, effects and control, New Age International, ISBN 8-12-241839-2, New Delhi. https://www.amazon.com/Water-PollutionCauses-Effects-Control/dp/8122418392

5. Hamid, A., Zeb, M., Mehmood, A., Akhtar, S. and Saif, S. (2013). Assessment of waste water quality of drains for irrigation. Journal of Environmental Protection, 4(09), p.937. http://dx.doi.org/10.4236/jep.2013.49108

6. Mehedi, Md., (2017). Analysis of Causes and Impact of Water Logging in Khulna City of Bangladesh, International Conference on Mechanical, Industrial and Materials Engineering 2017 (ICMIME 2017), RUET, Rajshahi, December 2017.

7. Metcalf and Eddy, (2003). Wastewater Engineering: Treatment and Reuse, 4th Edition, McGraw-Hill, ISBN 0-07-4622471, New York, USA. 
8. Mridha, U. K. (2011). Wastewater Characteristics of Khulna Municipal Area in Bangladesh. Water security in Periurban South Asia: Adapting to Climate Change and Urbanization Project.

9. Rahman, M. M., Akteruzzaman, A. K. M., Khan, M. M. H., Jobber, A. and Rahman, M. M. (2009). Analysis of Water Logging Problem and Its Environmental Effects Using GIS Approaches in Khulna City of Bangladesh. J. of Socioeconomic Research and Development, 6(2), pp.572-577.

https://www.cabdirect.org/cabdirect/abstract 120093161530

10. Rubel M, Chowdhury DA, Ahmed MJU, and Uddin MH. (2019). Physico-chemical characterization of kaptai lake and foy's lake water quality parameters in Chittagong, Bangladesh. Am. J. Pure Appl. Sci., 1(6), 4958.

https://doi.org/10.34104/ajpab.019.0194905 $\underline{8}$

11. Zheng, W., Li, X. M., Hao, Z. M., Wang, D. B., Yang, Q. and Zeng, G. M. (2010). Coal cinder filtration as pretreatment with biological processes to treat pharmaceutical wastewater. Water Science and Technology, 62(1), pp.15-20.

http://dx.doi.org/10.2166/wst.2010.244

Citation: Saju JA, Rubel SNR, Rahman MM, Nayan SB, and Bagchi R. (2020). Effectiveness of manual bar screen in separating solid waste from municipal sewers of Khulna city, Aust. J. Eng. Innov. Technol., 2(3), 31-41. https://doi.org/10.34104/ajeit.020.031041 